\title{
Culture-led Urban Transformation Strategies for Industrial Heritage and Industrial Areas in Istanbul
}

\author{
Serkan Sinmaz ${ }^{1 \odot}$, Aslı Altanlar $2 \odot$ \\ ${ }^{1}$ Faculty of Architecture, Kırklareli University, Kırklareli, Turkey. (Principal contact for editorial correspondence), Email: \\ serkansinmaz@klu.edu.tr \\ 2Faculty of Architecture, Amasya University, Amasya, Turkey. Email: asli.altanlar@amasya.edu.tr
}

\begin{abstract}
Purpose

In relation to the advances in information economics the flow of capital, creative industries, highspeed transportation systems and spatial characteristics of cities have led to the proliferation of cultural economics. In this respect, the departure of industry from cities is considered as a significant opportunity for the spatial improvement of cultural economics. Brownfields and industrial sites that are likely to abandon residential areas in the future stand out on account of their potential for transformation. Accordingly, this study aims to shed light on the spatial future of İstanbul, where development is currently aimed at achieving a global city, and to provide an analytical framework for the likely transformation of brownfields and idle industrial heritage sites.

\section{Design/Methodology/Approach}

For the purposes of this study, Suitability Analysis was utilized to evaluate industrial heritage sites that are no longer functional and industrial sites that hold the potential for transformation in İstanbul from the perspective of cultural development strategies. Therefore, first of all, the factors that influence site selection and agglomeration of cultural functions and cultural industries were created, weighed and mapped. Second, the components that specify the spatial preferences of entrepreneurial, creative class, and progressive strategies as well as the corresponding weighs of these components were identified. Finally, cultural development strategies that may be used to address the industrial sites in İstanbul with the potential for transformation, and the weighs of these strategies were revealed by using the "multi-criteria evaluation" method.

Findings

Culture-led transformation is typically shaped with the high-income target of entrepreneurial strategies. However, the transformation process should be reinforced with creative and progressive strategies. In this context, sites that are favourable for transformation in İstanbul accommodate an immense potential for entrepreneurial strategies, while the Bosporus as well as the Historic

Research Limitations/Implications

This study focuses on the province of İstanbul, which has the strongest connection to the network of global cities. The theoretical framework and materials for this study are made up of the available body of literature, digital maps, plans and plan reports.

\section{Originality/Value}

This study provides a platform for planners and authorities to discuss the culture-led regeneration of industrial heritage sites and brownfields with a focus on the medium- and long-term plans, programs and decisions for İstanbul. In addition, it contributes to the planning literature by offering a perspective on content and methodological approach for similar studies.
\end{abstract}

Keywords: Cultural development strategies, cultural industries, creative industries, transformation of industrial sites, İstanbul. 


\section{INTRODUCTION}

The future of cities at the urban and regional scales are defined by the ability of the capital to adapt to the outcomes of the ever-developing information economics and the goal to gain competitive edge. Accordingly, technological advancements, which trigger the departure of industrial facilities from cities, enable the maintenance of production and management in regions remote from each other, thus further encouraging an economic reconfiguration that relies on service industries. In this context, the notion of "culture" is considered as a key factor for urban development in terms of local economic development, employment generation, sustainability of the culture, urban image, improved quality of life, etc. (Niu, Lau, Shen, and Lau, 2018, p. 502). In this context, the primary objectives of cultural development strategies are to restructure urban economies and to deliver various approaches to configure cities and regions as centers for creativity and information by attracting capital, investments, qualified work force, and tourists (Degen and Gacia, 2012, p. 7-8; Grodach and Loukaitou-Sideris, 2007, p. 352). Such approaches aimed at the regeneration of urban space adopt strategies that, on one hand, support creative industries, create science and technology corridors, and improve cultural industries, and they embrace strategies that seek to achieve significant and influential architecture projects, cultural clusters and vibrant cities that live around the clock (Degen and Gacia, 2012). Given that this study is focused on spatial preferences to formulate cultural strategies, İstanbul is selected as the case study area on the grounds of its geographic features, its historic, cultural and natural assets, its location within the global network, its socially, economically and culturally diverse and dynamic composition, and its background as a European Capital of Culture. On the other hand, when the spatial evolution of culture industries is scrutinized, the transformation of idle sites and incompatible functions in the built environment presents a potential (Niu, Lau, Shen and Lau, 2018, p.516; Camerin, 2019, p. 2). Accordingly, idle industrial heritage sites in residential areas as well as industrial sites located in residential areas that hold the potential for transformation are considered with this perspective. Furthermore, in its 2010-2014 Strategic Plan, the İstanbul Metropolitan Municipality calls for the redevelopment of abandoned industrial sites within the city as cultural sites (IMP, 2009). In reference to Grodach and Loukaitou-Sideris' study (2007), cultural development strategies that may be adopted in potential transformation areas can be addressed in three categories. In their research that aims to comprehend the marketing and development of cultural activities by local governments and agencies in American cities, Grodach and Loukaitou-Sideris (2007) examine culture-led development strategies in three categories (namely, entrepreneurial strategies, creative class strategies, progressive strategies) (Grodach and Loukaitou-Sideris, 2007, p.352). 
The present study proposes that culture-led development strategies should be considered during the planning of 45 sites that were identified by means of fieldwork and the analysis of technical documents. Furthermore, it provides a framework for policymakers so as to identify what type of cultural development scenario is more appropriate for each site. The proposed framework scrutinizes the potential future transformation projects and provides an objective perspective that can be capitalized on for planning efforts. In respect to the planning process in İstanbul, it opens the floor for discussion on entrepreneurial strategies that may prove to be an economic attraction for the city, on creative strategies that present value in the competition between cities, and on progressive strategies that may help improve the social-spatial infrastructure of the city.

In this context, the first chapter provides the definition of urban cultural policies and addresses the notion of "culture industry." The typology of culture-led development strategies is presented in the second chapter. In the third chapter, the analytical method that is formulated to reveal the culture-led development potential in industrial heritage sites is tested in İstanbul. The last chapter provides a discussion on the opportunities and threats for the future of İstanbul presented by industrial heritage sites that carry the potential for transformation.

\section{LITERATURE REVIEW}

\section{Urban Cultural Policies and Cultural Industries}

Cultural policies and cultural industries are strategic development dynamics for cities of the 21st century. The allocation of public funds to culture is not a new practice. Nowadays, however, cultural strategies have gained a different character. Investing in culture and improving the global competitiveness and image of cities through culture have become a common policy tool for both central and local authorities (Grodach and Loukaitou-Sideris, 2007, p. 351-353). In this process, sectors known as "culture industries" have been evaluated within the framework of urban revitalization policies (Hospers and Pen, 2008, p. 259; Teper, 2002, p.162-164).

The term "culture industry" was first coined by Theodor Adorno and Max Horkheimer in their work titled "Dialectics of Enlightenment," published in 1947. Adorno and Horkheimer used the term "culture industry" to express the mass culture of the late capitalist world, and they held the culture industry responsible for the reification that emerged due to the management of culture through commodification and homogenization (Adorno, 2009, p.18-23; Montgomery, 2007, p.601).

Cultural economics and industries have lately been identified as "creative sectors/ industries." It is reasonable to argue that such an identification puts higher emphasis on creativity, thus concealing the commercial aspect of culture. These industries encompass a wide range of fields including music, performing arts, visual arts, publishing and 
broadcasting, handicrafts, advertising, architecture, computer and video games, software, design, environmental heritage, electronic and digital media, film, fashion design, other cultural goods, and manufacturing and sales (Montgomery, 2007, p.602; Banks and Hesmondhalgh, 2009, p.146; Trembath and Fielding, 2020). In the United States, cultural industries are grouped under four categories: core art field, cultural industries, creative industries and activities, and related industries (Özdemir, 2009, p.77).

The Department for Digital, Culture, Media and Sport (DCMS) in the United Kingdom has emphasized that culture industries are based on individual creativity, skills and talent, and it has also drawn attention to the potential these industries carry to improve their intellectual property and to create welfare and employment (Banks and Hesmondhalgh, 2009, p.146). For this reason, since the 1990s, culture industries, such as audiovisual media, informatics, recording and digital technologies, have been considered both as an important field of investment and as a significant source of employment (Montgomery, 2003, p.294; Lavanga, 2009, p.61-62). In 1996, the European Communication Commission highlighted numerous effects of culture in local development. The commission declared that "the increasing importance of culture in terms of regional development should be examined in contexts related to the restructuring of the economy as well as being the result of modified lifestyles" (Çelik, 2011, p.302). Similarly, in 1998, the New Labor Party in England opted for using the phrase "creative industries" instead of "cultural industries" in the party's cultural policy documents. In the first report prepared by the DCMS in 1998, "creative industries" are defined as "those industries which have their origin in individual creativity, skill and talent and which have a potential for wealth and job creation through the generation and exploitation of intellectual property." Since then, many governments expanded or narrowed the scope of the sector's activities, thus adapting this definition to their own cultural and/or creative industries (Lavanga, 2009, p. 63).

Chris Smith, former Secretary of State for Culture, Media and Sport in the United Kingdom (1998), stated that "Creative institutions and cultural developments are candidate to become a major concern for the modern world. It looks like creative professions will be the primary sector that generates employment in the next century" (Banks and O'Connor, 2017, p.638). Similarly, academician Shalini Venturelli (2000) expresses her opinion as "Employment growth is linked to the continuity of a country's creative structures. Economies that are not made up of creative teams will inevitably suffer." (Venturelli, 2000 as cited in Teper, 2002: 160). Evidently in its report on local economies, the National Governors Association emphasizes the fact that, in recent years, innovative commercial professions and nonprofit organizations has been the main input for the success of regional development projects. The data show that creative sectors in OECD member countries 
grow double the rate of the service industry and four times the rate of the conventional production industry (Robinson 2001, p. 42 as cited in Teper, 2002: 160). Evidently, in recent years, cultural industries have become a common interest and concern for all sectors in urban development programs, and the intensive use of cultural industries in urban development programs has led to the proliferation of publicprivate partnerships (Grodach and Loukaitou-Sideris, 2007, p. 350-351; Kuzmann, 2004, p.383-384). As one of the leading countries in this competition, the United Kingdom has set its cultural policies as follows:

- developing the knowledge interface,

- improving the demand-supply relationship,

- securing a high quality physical, social and cultural environment, and

- ensuring that all city-region inhabitants benefit from regional economic growth (Bontje and Musterd, 2009, p.846).

In line with these purposes, in 2005, the DCMS launched the Creative Economy Program (CEP). In addition to branding the United Kingdom as "the creative center of the World," the Creative Economy Program also aims to increase the number of professions involved in cultural industries (Banks and Hesmondhalgh, 2009, p. 422).

Also involved in this competition are cities such as Amsterdam, Munich and Helsinki that specialize in information and communication technologies, thus creating conditions that encourage creative business groups. Cultural industries, as in United Kingdom, are among the primary tools that local development agencies in Finland and Germany use to develop cities and regions (Bontje and Musterd, 2009, p. 348). In a similar fashion to many industrial cities in Western Europe, Barcelona placed culture in the center of its transformation efforts in the backdrop of global competition (Camerin, 2019, p. 2). In this respect, particularly in the city's third strategic plan enacted in 1999, Barcelona was presented as "a creative and information-based metropolitan area that is well-connected to the world and capable of providing economic opportunities to its residents" (Marshall, 2000, p. 308). Kong (2000) refers to this period as "cultural economic policy," and outlines its four characteristics as follows: a) sustaining of infrastructure investments necessary for cultural production (creating cultural clusters/regions, marketing, etc.), b) hosting mega-events as well as flagship arts developments related to the city's local cultural heritage, thus encouraging culture tourism, c) revitalization of urban spaces, and d) significant increase in public-private partnerships (Kong, 2000, p.387 as cited in Garcia, 2004, p.315).

Attracting high-income professionals with the help of creative urban discourses has also become a trend. In this context, as an effort to strengthen their urban image and for branding purposes, local governments began making spatial plans within the framework of revitalization themes by developing strategies on these trends that aim to increase the consumption rate of local residents and tourists by 
means of cultural industries (Kunzmann, 2004, p.383; Florida, 2003, p.3). Whilst designing town centers, many strategies were used such as amenity bonuses, tax credits, land writedowns to promote highlyrecognized constructions and modernize industrial buildings for cultural purposes. Numerous other cities also allocated budgets for public art programs in order to artistically enrich renovation activities. With the aim to revitalize abandoned industrial areas, more than 90 cities in the United Stated had designated arts regions before the 1990s. Most of these tried to gain success, and even mark the beginning of a new epoch, by constructing a high-end cultural building as an effort to promote the city (Grodach, 2017, p.83). In other words, many attempted to achieve their own "Bilbao effect" by means of a high-concept cultural building to brand the city. These include the Yerba Buena Center for the Arts in San Francisco, Art Gallery of Ontario in Toronto, the Temple Bar in Dublin, and the Arts District in Dallas. Coupled with the promotional efforts, the cultural development initiatives of local governments led to a complete boost of cultural activities (Grodach, 2017, p. 83; Grodach and Loukaitou-Sideris, 2007, p.351; Montgomery, 2007, p. 610-611).

With the advances in technology and the emergence of new production systems, former industrial cities aimed to restore their place in the urban competition by repurposing brownfields through cultural development strategies. In this context, the old armory in Beijing was transformed as an arts district (Niu, Lau, Shen and Lau, 2018); the power station Shanghai was regenerated as a contemporary arts museum; the Zollverein Coal Mines, the Herne Hulsmann Brewery, and the Oberhausen Gasometer in in Essen in the Ruhr region were regenerated as a shopping center, cultural center and museum (Saner, 2011, p.270); the Bankside Power Station in London was repurposed as the Tate Modern art museum and gallery; the Custard Factory in Birmingham was regenerated as an arts and media complex; the chocolate factory in Wood Green, London was repurposed for fine arts, handicrafts, textile design, and film studios (Montgomery, 2007, p.606607).

Another culture-led urban transformation project is the 22@Barcelona in Barcelona's Poblenou neighborhood. In scope of the project, the Barcelona Industrial Culture Center, Barcelona Media Park, a shared campus for universities, headquarters of design companies, medical technology hub, offices and R\&D centers of energy companies, headquarters of IT companies were established in Poblenou, which was once home to industrial facilities and warehouses. Furthermore, the 22@Barcelona project provided numerous programs to develop capacity, improve technology knowledge and use, and improve the quality of live of those who live and work in the neighborhood (Camerin, 2019, p. 8-9).

In Turkey, on the other hand, fine examples of industrial heritage sites are found particularly in İstanbul, İzmir, and Eskişehir, and when compared to Europe, few of these sites are conserved and/or 
regenerated for cultural purposes. Out of these, the Silahtarağa Power Plant in İstanbul that was regenerated as an educational and cultural facility stands out as an interesting project. The "lengerhane" building (a building used for casting anchors and chains) and the Hasköy Dockyard, which were regenerated as the first industrial museum in Turkey by the Rahmi M. Koç Museology and Cultural Foundation, are the finest examples where the industrialization along the Golden Horn can be observed in situ (Köksal , 2012, p. 23). In addition, Ankara TCDD (Turkish State Railways) Train Hangars were repurposed as a contemporary arts museum, İzmir Pasaport Ferry Terminal and its warehouses were regenerated as a cultural center and a shopping mall, and the winery in Eskişehir was regenerated as Hayal Kahvesi (a restaurant and a venue for live music) (Cengizkan, 2012, p.28).

The number of examples, only a limited amount of which are presented in this paper, has been on the rise, and the topic draws increased attention in Turkey similar to the case in Europe. The intellectual and actional reuse of these facilities, which once played a critical role in the evolution of cities and life, by preserving their value and by ensuring public interest not only reintroduces the industrial heritage to contemporary life but also ensures high-quality contribution to urban life. Increasing awareness on the subject, conserving industrial buildings with different functions and value in different regions of the country before they get dilapidated, and reusing these buildings for public good will also lead to favorable outcomes in terms of improving the quality of life (Köksal , 2012, p. 23).

\section{Culture-led Urban Development Strategies}

According to Evans (2005, p.968), culture-led development models that include cultural programs and activities in the revitalization process can be classified as culture and regeneration, cultural regeneration, and culture-led regeneration. However, he states that these three models may not differ much from each other in the process (Evans, 2005, p.968969).

If cultural efforts and regeneration are led by separate authorities, the culture and regeneration model would typically be the first model used. In this case, although culture contributes to regeneration, it is not possible to integrate culture while developing urban designs or main projects. Accordingly, a powerful local or global leader who can endeavor against negative social views and ideas to strengthen the effect of culture on regeneration, and who attaches importance to integrating cultural activities as well as preserving ethnic groups and values is needed for this model (Chiu, Lee, and Wang, 2019, p. 2).

The second model, cultural regeneration, is a more inclusive and coordinated model at the policy level, and it involves questioning at the level of cultural policies and strategies. Such interventions are often smaller in scale, such as a public art program for office development or a local history museum hidden in an industrial site. It should be noted, 
however, that the absence of any noticeable cultural activity or provision in such a resuscitation strategy does not mean that there is no cultural activity, it only indicates that culture is not organized or supported as part of the process. In this approach, the main reason behind why culture is addressed as a supplement rather than a part of the revitalization strategy is the fact that relevant authorities, organizations and individuals that formulate revitalization plans and those in charge of cultural activities do not consider each other as stakeholders, thus avoiding collaboration (Evans, 2005, p. 969; Chiu, Lee and Wang, 2019, p. 2).

The third model, culture-led urban regeneration, encompasses interventions that involve cultural programs and activities where public interest is a priority. These interventions are typically a means of attracting attention and generating enthusiasm for revitalization programs in their entirety. In other words, the investment programs formulated for culture-led revitalization are aimed at social development, and they do not necessarily entail any economic objectives (such as increase in real estate values, etc.). In these models, physical renewal is performed with the aim to ensure the availability of cultural activities and programs (Evans, 2005, p.968). Moreover, such interventions should encourage the construction of new commuting systems, the renovation of the current social and cultural premises, or the building of first-class hotels. Raising local support and approval is extremely essential for all these actions (Chiu, Lee, and Wang, 2019, p. 2).

Grodach and Loukaitou-Sideris (2007: 352) summarize three different models as culture-led development strategies in their research that aims to understand the marketing and development activities process of cultural activities of carried out by local governments and agents in American cities: (1) Entrepreneurial strategies, (2) Creative class strategies, (3) progressive strategies (Table 1).

Entrepreneurial strategies: Almost all of them are focused on economic development rather than social goals. In this approach, local governments try to create an attractive environment for investments by means of regulations such as tax deductions, land allocation and flexible zoning practices. Cities are marketed through large-scale prestige projects, and private sector investments are sought. In this process, city authorities attempt to increase the competitiveness of their cities in terms of the developing industries of the "new economy," such as tourism, culture and information technologies. Cultural projects are considered as important tools for enhancing the image of cities and creating a "brand." These strategies have been criticized for trying to develop cities with the help of investors, tourists and the wealthy rather than the residents of the city, and for departing from the principle of community benefit by granting privileges to the private sector (Grodach and Loukaitou-Sideris, 2007, p. 353). 
Culture-led Urban Transformation Strategies For Industrial Heritage And Industrial Areas In Istanbul

Table 1. Cultural development strategies (Grodach and Loukaitou-Sideris, 2007, p. 352).

\begin{tabular}{|c|c|c|c|}
\hline $\begin{array}{l}\text { Cultural } \\
\text { Developmen } \\
\text { t Strategies }\end{array}$ & $\begin{array}{l}\text { Entrepreneurial } \\
\text { Strategies }\end{array}$ & $\begin{array}{l}\text { Creative Class } \\
\text { Strategies }\end{array}$ & $\begin{array}{l}\text { Progressive } \\
\text { Strategies }\end{array}$ \\
\hline Goals & $\begin{array}{l}\text { - Economic } \\
\text { development through } \\
\text { tourism and city image } \\
\text { - Catalyst effect on } \\
\text { private sector } \\
\text { investments }\end{array}$ & $\begin{array}{l}\text { - Economic } \\
\text { development } \\
\text { through quality of } \\
\text { life } \\
\text { - Attracting new } \\
\text { residents in the } \\
\text { creative economy }\end{array}$ & $\begin{array}{l}\text { - Community } \\
\text { development } \\
\text { - Arts education } \\
\text { and access to art } \\
\text { - Local cultural } \\
\text { production }\end{array}$ \\
\hline $\begin{array}{l}\text { Types of } \\
\text { Cultural } \\
\text { Projects and } \\
\text { Programs }\end{array}$ & $\begin{array}{l}\text { - Flagship cultural } \\
\text { projects } \\
\text { - Spectacular events } \\
\text { - Promotional } \\
\text { activities }\end{array}$ & $\begin{array}{l}\text { - Arts and } \\
\text { entertainment } \\
\text { districts } \\
\text { - Collaboration } \\
\text { between arts and } \\
\text { private sector }\end{array}$ & $\begin{array}{l}\text { - Community } \\
\text { centers } \\
\text { - Arts education } \\
\text { programs }\end{array}$ \\
\hline $\begin{array}{l}\text { Geographic } \\
\text { Focus }\end{array}$ & $\begin{array}{l}\text { - Downtown } \\
\text { - Old historical areas }\end{array}$ & $\begin{array}{l}\text { - Downtown and } \\
\text { historic urban } \\
\text { neighborhoods }\end{array}$ & $\begin{array}{l}\text {-Inner-city } \\
\text { neighborhoods } \\
\text {-Underserved } \\
\text { neighborhoods } \\
\end{array}$ \\
\hline $\begin{array}{l}\text { Target } \\
\text { Audience }\end{array}$ & $\begin{array}{l}\text { - Tourists and } \\
\text { conventioneers } \\
\text { - Affluent "residents" } \\
\text { and suburbanites }\end{array}$ & $\begin{array}{l}\text { - Prospective and } \\
\text { existing residents } \\
\text { - Young } \\
\text { professionals and } \\
\text { knowledge-based } \\
\text { workers }\end{array}$ & $\begin{array}{l}\text {-Underserved } \\
\text { residents }\end{array}$ \\
\hline Criticisms & $\begin{array}{l}\text { - The argument that } \\
\text { they depart from the } \\
\text { principle of } \\
\text { community benefit } \\
\text { - Privileges granted to } \\
\text { the private sector } \\
\text { - The neglect of urban } \\
\text { issues (such as } \\
\text { poverty, crime, } \\
\text { homelessness, etc.) } \\
\text { - Initiatives for } \\
\text { investors, tourists, and } \\
\text { the wealthy }\end{array}$ & $\begin{array}{l}\text { - The argument } \\
\text { that it would } \\
\text { result in a biased } \\
\text { economic } \\
\text { development } \\
\text { program for the } \\
\text { benefit of a single } \\
\text { class } \\
\text { - Its focus on the } \\
\text { construct of a } \\
\text { living } \\
\text { environment that } \\
\text { responds to the } \\
\text { expectations of } \\
\text { the creative class } \\
\text { - The threat of } \\
\text { "gentrification" in } \\
\text { the downtown } \\
\text { and in historical } \\
\text { neighborhoods, } \\
\text { which are } \\
\text { appealing for the } \\
\text { creative class }\end{array}$ & $\mathrm{N} / \mathrm{A}$ \\
\hline
\end{tabular}

Creative class strategies: They try to attract the "creative class" to the city by focusing on improving the quality of life and providing opportunities to respond to a certain lifestyle. Therefore, they strive to create an urban environment that would be appealing for this class with attributes such as being open to new ideas, tolerant, culturally diverse and multifunctional, featuring a well-preserved historical identity, and 
offering various cultural and recreational opportunities. In this scenario, cultural activities are very important because they respond not only to the consumption habits but also to the entertainment \& leisure needs and the cosmopolitan identity of the creative class. By contrast with the entrepreneurial approach, the creative class approach promotes clusters of small-scale cultural and art venues. Advocates of this approach state that the economic benefit that is generated by the attraction of the creative class into the city will disperse to other segments of society and will spread to the numerous segments with help of the low-wage jobs created in the service sector. Some experts, on the other hand, criticize this approach on account of being for the benefit of a single class, thus arguing that it would result in a biased program of economic development. They also argue that, although the goal to ensure ethnic diversity, a clean environment and access to art are quite important in essence, they are actually aimed at creating a living environment that will respond to the expectations of the creative class rather than providing benefit to the general public. Finally, when a creative city is built with this approach, the downtown and historical neighborhoods, which are the center of attraction for the creative class, will face the threat of gentrification (Peck, 2005, p. 746; Grodach and Loukaitou-Sideris, 2007, p.354).

Progressive strategies: The main objective of this approach is to increase the standards for everyone by means of redistribution policies that support economic and social inequality, and participatory practices. Progressive strategies strive to return the advantages granted to the private sector with the zoning and development rights to the general public, and for this purpose, they impose high taxes and/or seek developer obligations such as the improvement of the built and the natural environment, the provision of affordable housing, and the promotion of public transportation in return for the zoning rights granted. Furthermore, progressive cultural strategies aim to promote access to art and culture and to support local cultural production, they also seek to improve disadvantaged neighborhoods through culture and art, and to strengthen the sense of social identity and belonging. In short, they look for methods to ensure that benefits generated by cultural development are distributed to wider audiences (Grodach and Loukaitou-Sideris, 2007, p. 355).

In light of these details, the purpose of integrating culture to civic regeneration is to draw the attention of innovative minds and industries to a certain region for environmental improvement. It also aims to create places and environments, highlight and commercialize local amenities, and maintain historical and cultural attributes. Cultural identity can spark regional confidence and agreement and can also ensure receiving approval and the trust of the community. Therefore, it is possible to suggest that community agreement and trust -and not the regeneration strategies themselves- are what identifies culture-led urban regeneration (Chiu, Lee, and Wang, 2019, p. 7). 


\section{CULTURE-LED URBAN TRANSFORMATION AND İSTANBUL}

With its geographical, political, cultural, social, and economic characteristics, İstanbul is one of the oldest settlements that served as an important hub for numerous cultures. In addition to its rich cultural and historical context, it also plays an important role in terms of capital and employment. İstanbul did not experience de-industrialization to the same extent as Western cities. On the contrary, the manufacturing industry still has a significant share in the city's economy. ${ }^{3}$ However, the decentralization of the industry has been a policy that has persisted since the 1960s. As a result of both the changing needs of industrial production and the policies aimed at clearing the city from industry, there are numerous idle industrial sites in İstanbul. These areas are now being considered within the scope of revitalization policies. For example, the repurposing of the Cibali Tobacco Factory, Feshane (fez factory), Lengerhane (a building used for casting anchors and chains), Silahtarağa Power Plant, which are identified as industrial archeology in the Golden Horn Master Plan Report, from their manufacturing function into a cultural function as well as İstanbul Metropolitan Municipality's proposal to regenerate idle industrial areas within the city with cultural activity areas in the 2010-2014 Strategic Plan are the indicators of this trend. This trend makes it important to make a spatial evaluation of the transformation potential of existing industrial areas that hold the potential for transformation as well as industrial heritage sites in terms of cultural development strategies.

In this study, which aims to make such an evaluation and to draw attention to alternative scenarios, industrial heritage areas in İstanbul and industrial sites with the potential for transformation in İstanbul were identified first. In order to do so, a five-stage evaluation process was formulated, a total of 45 industrial sites were identified, and their boundaries were determined. Secondly, Suitability Analysis was performed. In order to evaluate the level of suitability of each one of the 45 sites for urban transformation within the framework of cultural development strategies, various criteria and the significance level of these criteria were identified based on the data on centrality, accessibility, historical quality, and plan decisions (Koramaz, 2016, p. 129-130). As a result of the analysis, a quantitative value was obtained for each area that holds the potential for transformation. Then, spatial preferences criteria were specified to determine which cultural development strategies could be prioritized in these areas. At this stage, based on the criteria determined previously, the primary and secondary strategic approaches were determined for each site in the percentile system. Finally, the culture-led strategies that can be evaluated for the repurposing of industrial areas that hold the potential for transformation and cultural heritage areas in İstanbul were discussed, and the opportunities and threats related to these strategies were put forward. 
Industrial Heritage and Industrial Sites in İstanbul with Transformation Potential Industrial heritage sites in İstanbul: Cultural industries based on the local production system feature strong spatial characteristics. Cultural industries:

- are typically, small and medium-sized,

- need a great deal of physical proximity between each other, with a high tendency to cluster,

- depend on the inputs and infrastructures of the locallyspecialized labor market,

- require effective communication and face-to-face interaction, and

- depend on local social networks, thus requiring a robust transportation network.

Considering these features of cultural industries, industrial heritage sites, which are likely to undergo transformed, prove to be an important potential. Therefore, the industrial heritage sites in İstanbul are identified in this section. For this purpose, the industrial heritage areas listed by Köksal and Ahunbay (2006) were examined, and out of these areas, sites that are still operational, sites for which a project and an implementation plan are prepared, sites that were already regenerated were excluded. Only the areas that are currently being planned, that remain idle, and that are unplanned were included in the scope of the study. Consequently, 16 idle industrial sites were identified and shown on the map within the context of mentioned criteria (Figure 1) (Table 2). Industrial sites with transformation potential in Istanbul: In this section, a five-stage evaluation process was applied by examining the data obtained from the İstanbul Metropolitan Planning Office (IMP) to determine the industrial sites that hold the potential for transformation and can be evaluated within the framework of cultural development strategies.

In Stage I, organized industrial zones (OIZs) were excluded from all existing industrial sites.

In Stage II, structures other than those with 'manufacturing and warehouse function' were excluded from all existing industrial sites in order to identify sites that are used for production purposes only.

In Stage III, technology development areas, dockyards, advanced technology areas, innovative technology industrial sites specified in the Draft 1/25,000 Environmental Plan were included as potential areas in terms of cultural development strategies.

In Stage IV, areas that are planned to be transformed as service, public facility, technology development, housing, tourism, and recreation areas in the Draft 1/25,000 Environmental Plan were superimposed onto the areas identified in the previous stages, thus all sites with transformation potential were identified.

In Stage $V$, the maps created in the first four stages were superimposed, thus areas that tend to cluster were detected and their boundaries were identified (Figure 1). 
Culture-led Urban Transformation Strategies For Industrial Heritage And Industrial Areas In Istanbul

As a result of all these stages, a total of 45 sites that hold significant transformation potential and that stand out in terms of cultural development strategies were identified in İstanbul (Table 2).

Figure 1. Idle industrial heritage areas $(\mathrm{x})$ and industrial sites with transformation potential in İstanbul, 2018.

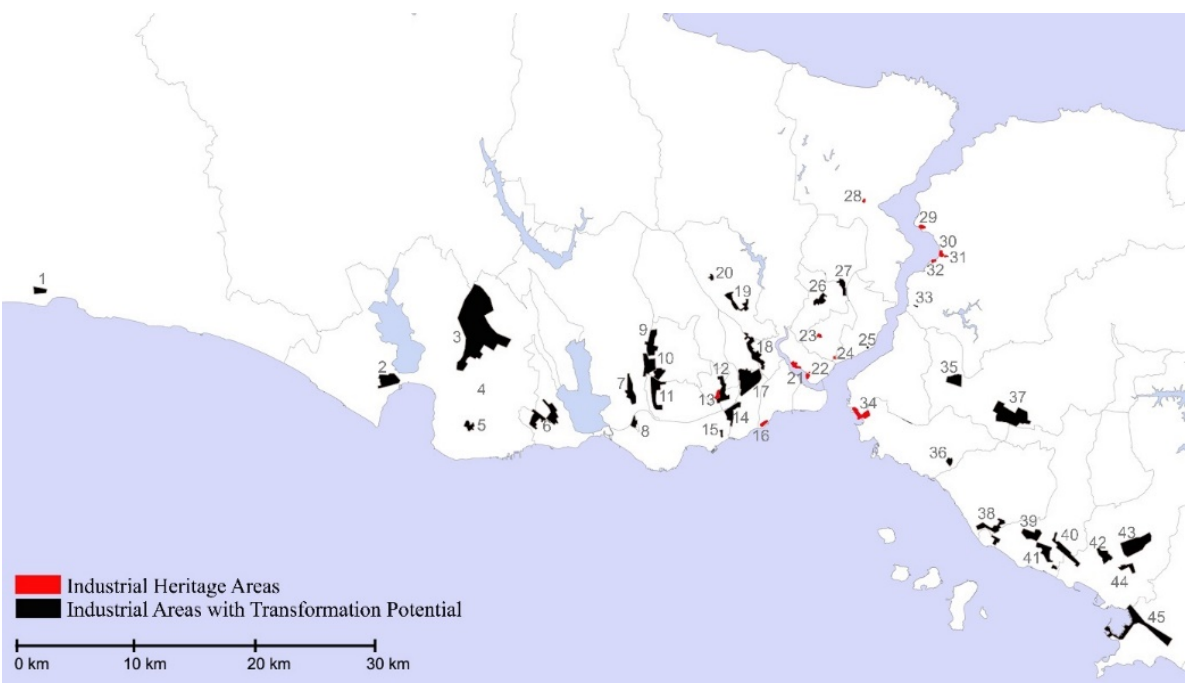

Table 2. Idle industrial heritage Areas (x) and industrial sites with transformation potential in İstanbul, 2018

\begin{tabular}{|c|c|c|c|c|c|}
\hline 1 & Silivri & 16 & Yedikule Gashouse (x) & 31 & $\begin{array}{l}\text { Beykoz Brick } \\
\text { Factory (x) }\end{array}$ \\
\hline 2 & Büyükçekmece & 17 & Zeytinburnu 2 & 32 & Beykoz Distillery (x) \\
\hline 3 & Beylikdüzü 1 & 18 & Bayrampaşa - Eyüp & 33 & $\begin{array}{l}\text { Beykoz Rope } \\
\text { Factory }\end{array}$ \\
\hline 4 & Beylikdüzü 2 & 19 & Gaziosmanpaşa & 34 & $\begin{array}{l}\text { Haydarpaşa Railway } \\
\text { Station Atelier }(\mathrm{x})\end{array}$ \\
\hline 5 & Beylikdüzü 3 & 20 & Sultangazi & 35 & Ümraniye 1 \\
\hline 6 & Avcllar & 21 & Haliç Dockyards (x) & 36 & Ataşehir \\
\hline 7 & Küçükçekmece & 22 & $\begin{array}{l}\text { Kasımpaşa Flour } \\
\text { Factory }(\mathrm{x})\end{array}$ & 37 & Ümraniye 2 \\
\hline 8 & Bakırköy 1 & 23 & Bomonti Beer Factory $(\mathrm{x})$ & 38 & Maltepe 2 \\
\hline 9 & Bağcılar 1 & 24 & Dolmabahçe Gashouse (x) & 39 & Kartal 1 \\
\hline 10 & Bağcılar 2 & 25 & $\begin{array}{l}\text { Ortaköy Pharmaceutical } \\
\text { Plant }\end{array}$ & 40 & Kartal 2 \\
\hline 11 & Bahçelievler & 26 & Kağıthane 1 & 41 & Kartal 3 \\
\hline 12 & Güngören & 27 & Kağıthane 2 & 42 & Pendik 1 \\
\hline 13 & $\begin{array}{l}\text { Haznedar Brick } \\
\text { Factory }(\mathrm{x})\end{array}$ & 28 & $\begin{array}{l}\text { Büyükdere Match Factory } \\
\text { (x) }\end{array}$ & 43 & Pendik 2 \\
\hline 14 & Zeytinburnu 1 & 29 & Beykoz Shoe Factory (x) & 44 & Pendik 3 \\
\hline 15 & Bakırköy 2 & 30 & Beykoz Glass Factory (x) & 45 & Tuzla \\
\hline
\end{tabular}

Evaluation of the Level of Suitability for Urban Transformation of the Designated Areas Under Cultural Development Strategies

In order to evaluate the designated areas in terms of cultural development strategies, the researchers referred to the site-selection trends of cultural functions and culture industries based on the available literature, and identified five criteria. These criteria were then assigned a numeric value to reach a quantitative result. These criteria include 
centrality, accessibility via different modes of transportation, historical attributes, and upper-scale plan decisions.

Centrality: Given the fact that being in or near the center are considered as an opportunity for the development of cultural industries, distance to the urban center was considered as a priority in the evaluation (Figure 2).

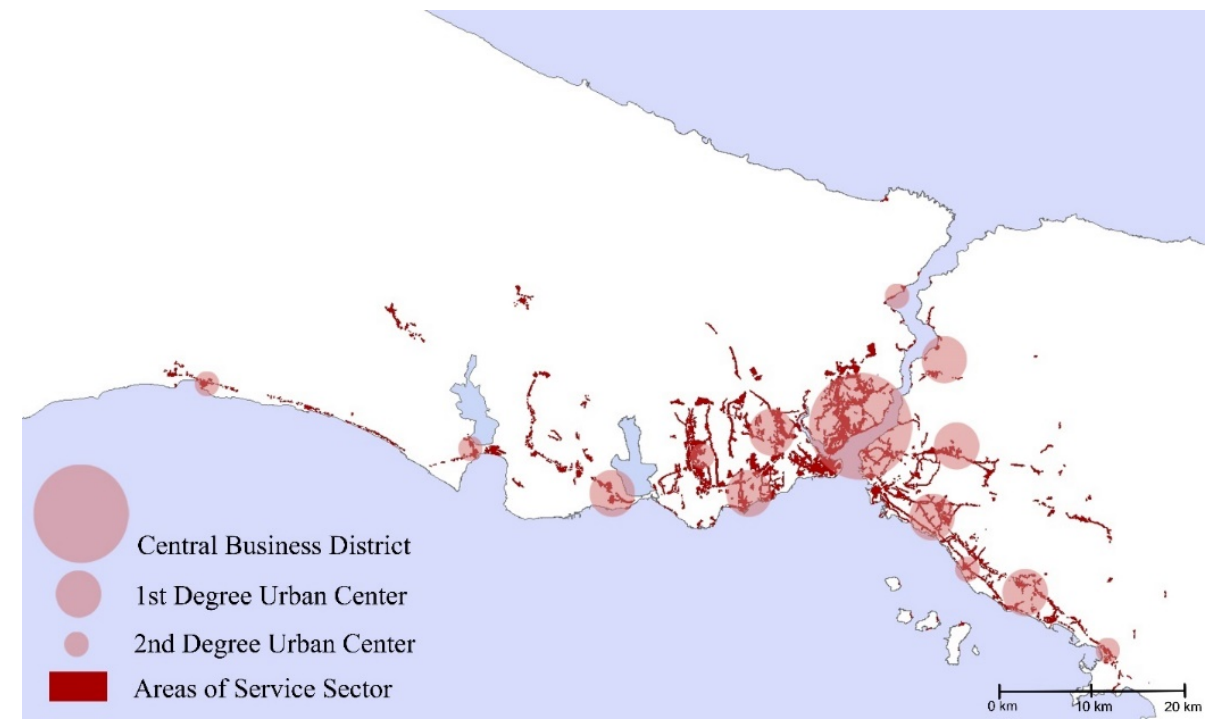

Accessibility (via private and public transportation): Decisions on transportation policies and programs for the İstanbul metropolitan area prove to be one of the most important determinants of the city's macroform; therefore, it has been taken into account as one of the decisive criteria in the culture-led transformation of the areas with the transformation potential. In order to determine the level of integration and accessibility of the designated areas to the city, accessibility was examined under two sub-criteria (namely, public transportation and private transportation) (Figure 3).

Historical attributes: As mentioned previously, cultural development strategies primarily prefer structures or areas with an authentic identity and historical character that can be transformed by repurposing.

Planning decisions: Several studies produced during the strategic planning process of the İstanbul metropolitan area in 2006 as well as the İstanbul Environmental Plan in 2009 were considered as references. Based on these planning activities,

- the "development districts for cultural industries" that were proposed in the course of the strategic planning process for İstanbul (IMP, 2006a),

- the "industrial areas that will be transformed" (IMP, 2006b) specified in the synthesis of industrial sites in the İstanbul strategic planning process, and
Figure 2. Current centers in Istanbul (IMM, 2018). 
Culture-led Urban Transformation Strategies For Industrial Heritage And Industrial Areas In Istanbul

- the service, tourism, recreation, technology development and residential areas that are identified in the $1 / 25,000$ Environmental Plan for İstanbul

were used as basis during the evaluation process (Figure 4) (IMP, 2009).

Figure 3. Private and public transportation in Istanbul (IMM, 2018)

Figure 4. Transformation areas and functions determined in the $1 / 25,000$ environmental planning process (IMP, 2009).
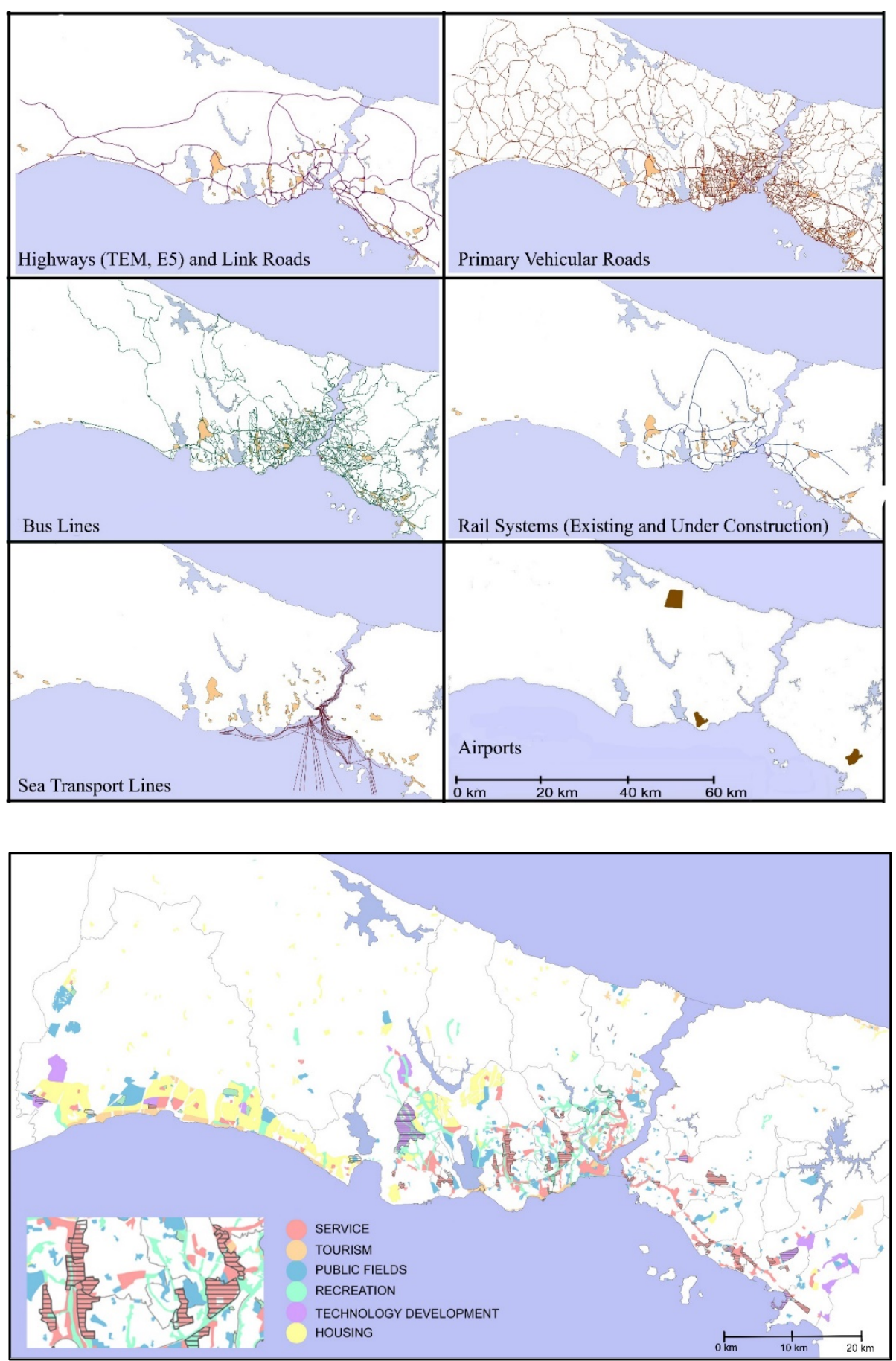

Based on the criteria and the scoring system presented in Table 3, the total score of each area was determined, and the suitability level of these areas for urban transformation with help of cultural development strategies was calculated (Table 3). 
Table 3. Criteria and cores that were used to evaluate the areas from a perspective of cultural development strategies

\section{CRITERIA}

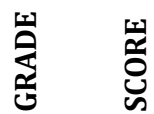

\begin{tabular}{|c|c|c|c|}
\hline \multirow{9}{*}{ ENTRALITY [C] } & \multicolumn{3}{|l|}{ Centricalness } \\
\hline & Located in the impact area of the CBD & High & 3 \\
\hline & $\begin{array}{l}\text { Located in the impact area of a 1st degree } \\
\text { urban center }\end{array}$ & Medium & 2 \\
\hline & $\begin{array}{l}\text { Located in the impact area of a 2nd degree } \\
\text { urban center }\end{array}$ & Low & 1 \\
\hline & \multicolumn{3}{|l|}{ Distance } \\
\hline & Located in the CBD & $\begin{array}{l}\text { Very } \\
\text { high }\end{array}$ & 4 \\
\hline & $10 \mathrm{~km}$ distance to the CBD & High & 3 \\
\hline & $20 \mathrm{~km}$ distance to the CBD & Medium & 2 \\
\hline & $30 \mathrm{~km}$ distance to the CBD & Low & 1 \\
\hline \multirow{4}{*}{$\begin{array}{l}\text { PRIVATE } \\
\text { TRANSPORTATION } \\
\text { [PT] }\end{array}$} & $\begin{array}{l}\text { Proximity and connection level to main } \\
\text { traffic arteries }\end{array}$ & & \\
\hline & Located on the TEM and/or E5 highway & High & 3 \\
\hline & $\begin{array}{l}\text { High connectivity to the TEM and/or E5 } \\
\text { highway }\end{array}$ & Medium & 2 \\
\hline & $\begin{array}{l}\text { High connectivity to 1st degree vehicular } \\
\text { roads }\end{array}$ & Low & 1 \\
\hline \multirow{16}{*}{$\begin{array}{l}\text { PUBLIC } \\
\text { TRANSPORTATION } \\
\text { [PBT] }\end{array}$} & Proximity to bus lines & & \\
\hline & High proximity to existing lines $(400 \mathrm{~m})$ & High & 3 \\
\hline & $\begin{array}{l}\text { Medium proximity to existing lines (400-800 } \\
\mathrm{m})\end{array}$ & Medium & 2 \\
\hline & Low proximity to existing lines $(800+\mathrm{m})$ & Low & 1 \\
\hline & Proximity to rail transport lines & & \\
\hline & $\begin{array}{l}\text { High proximity to existing and under } \\
\text { construction lines }(800 \mathrm{~m})\end{array}$ & High & 3 \\
\hline & $\begin{array}{l}\text { Medium proximity to existing and under } \\
\text { construction lines }(800 \mathrm{~m}-2 \mathrm{~km})\end{array}$ & Medium & 2 \\
\hline & $\begin{array}{l}\text { Low proximity to existing and under } \\
\text { construction lines }(2-4 \mathrm{~km})\end{array}$ & Low & 1 \\
\hline & Proximity to sea transport lines (iskele) & & \\
\hline & High proximity to existing lines $(400 \mathrm{~m})$ & High & 3 \\
\hline & $\begin{array}{l}\text { Medium proximity to existing lines (400-800 } \\
\text { m) }\end{array}$ & Medium & 2 \\
\hline & Low proximity to existing lines $(800 \mathrm{~m}-2 \mathrm{~km})$ & Low & 1 \\
\hline & Proximity to airports & & \\
\hline & High proximity to existing airports (5 km) & High & 3 \\
\hline & $\begin{array}{l}\text { Medium proximity to existing airports (5 } \\
\mathrm{km}-10 \mathrm{~km})\end{array}$ & Medium & 2 \\
\hline & $\begin{array}{l}\text { Low-proximity to existing airports }(10 \mathrm{~km}- \\
15 \mathrm{~km})\end{array}$ & Low & 1 \\
\hline \multirow{2}{*}{$\begin{array}{l}\text { HISTORICAL } \\
\text { ATTRIBUTES [HA] }\end{array}$} & Cultural heritage areas & $\mathrm{N} / \mathrm{A}$ & 3 \\
\hline & Newly developed areas & $\mathrm{N} / \mathrm{A}$ & 0 \\
\hline \multirow{6}{*}{$\begin{array}{l}\text { PLAN DECISIONS } \\
\text { [PD] }\end{array}$} & $\begin{array}{l}\text { High proximity to the regions designated as } \\
\text { "development areas for cultural industries" } \\
\text { in the } 1 / 100,000 \text { Strategic Plan }\end{array}$ & $\mathrm{N} / \mathrm{A}$ & 3 \\
\hline & $\begin{array}{l}\text { High proximity to the industrial areas that } \\
\text { will be transformed in the synthesis of } \\
\text { industrial sites in the } 1 / 25,000 \\
\text { Environmental Plan }\end{array}$ & N/A & 3 \\
\hline & $\begin{array}{l}\text { Transformation functions defined in the } \\
1 / 25,000 \text { Environmental Plan }\end{array}$ & $\mathrm{N} / \mathrm{A}$ & 3 \\
\hline & Service - tourism & $\mathrm{N} / \mathrm{A}$ & 3 \\
\hline & Facilities (education, culture, recreation) & $\mathrm{N} / \mathrm{A}$ & 2 \\
\hline & High-tech production - housing & $\mathrm{N} / \mathrm{A}$ & 1 \\
\hline
\end{tabular}


In this scoring system, a certain site can receive maximum 30 points and minimum 3 points. According to the analysis, the areas that are suitable for urban transformation with help of cultural development strategies and the score for each area are shown in Table 4.

According to the calculation method,

- each field presented in Table 2 was analyzed according to the criteria in Table 3,

- the score related to each criterion in Table 3 is assigned for each field, and

- the scores assigned to each field in reference to the provided criterion are added up (Table 4).

The following method is used to evaluate the field of cultural development strategies:

*Total Score $=\mathrm{C}+\mathrm{PT}+\mathrm{PBT}+\mathrm{HQ}+\mathrm{PD}$

${ }^{*}$ Centrality [C]; Private transportation [PT]; Public transportation [PBT]; Historical attributes [HA]; Planning decisions [PD]

According to the calculation, industrial areas with the highest transformation potential are Haliç Dockyards (30 points), Haydarpaşa Railway Station Machine Shop (30 points), Kasımpaşa Flour Factory (29 points), Dolmabahçe Gashouse (29 points), and Bomonti Beer factory (28 points). On the other hand, Beylikdüzü-1 (7 points), Pendik-2 (8 points), Pendik-3 (10 points), and Sultangazi (10 points) prove to be the industrial areas with the lowest transformation potential.

Table 4. Designated industrial sites ordered by their level of suitability for urban transformation within the framework of cultural development strategies

\begin{tabular}{clcclc}
\hline Code & Name & Score & Code & Name & Score \\
\hline 21 & Haliç Dockyards & $\mathbf{3 0}$ & 8 & Bakırköy 1 & $\mathbf{2 0}$ \\
\hline \multirow{2}{*}{34} & $\begin{array}{l}\text { Haydarpaşa Railway } \\
\text { Station Machine Shop }\end{array}$ & $\mathbf{3 0}$ & 36 & Ataşehir & $\mathbf{1 9}$ \\
\hline \multirow{2}{*}{22} & $\begin{array}{l}\text { Kasımpaşa Flour } \\
\text { Factory }\end{array}$ & $\mathbf{2 9}$ & 30 & Beykoz Glass Factory & $\mathbf{1 9}$ \\
\hline 24 & $\begin{array}{l}\text { Dolmabahçe } \\
\text { Gashouse }\end{array}$ & $\mathbf{2 9}$ & 31 & Beykoz Brick Factory & $\mathbf{1 9}$ \\
\hline 23 & Bomonti Beer & $\mathbf{2 8}$ & 7 & Küçükçekmece & $\mathbf{1 9}$ \\
\hline 45 & Factory & $\mathbf{2 7}$ & 12 & Güngören & $\mathbf{1 8}$ \\
\hline 15 & Bakırköy 2 & $\mathbf{2 6}$ & 29 & Beykoz Shoe Factory & $\mathbf{1 7}$ \\
\hline 27 & Kağıthane 2 & $\mathbf{2 6}$ & 32 & Beykoz Distillery & $\mathbf{1 7}$ \\
\hline 41 & Kartal 3 & $\mathbf{2 6}$ & 37 & Ümraniye 2 & $\mathbf{1 7}$ \\
\hline 18 & Bayrampașa-Eyüp & $\mathbf{2 5}$ & 35 & Ümraniye 1 & $\mathbf{1 7}$ \\
\hline 38 & Maltepe & $\mathbf{2 5}$ & 33 & Beykoz Rope Factory & $\mathbf{1 5}$ \\
\hline 17 & Zeytinburnu & $\mathbf{2 5}$ & 19 & Gaziosmanpaşa & $\mathbf{1 4}$ \\
\hline 26 & Kağıthane 1 & $\mathbf{2 5}$ & 4 & Beylikdüzü & $\mathbf{1 4}$ \\
\hline 11 & Bahçelievler & $\mathbf{2 4}$ & 42 & Pendik 1 & $\mathbf{1 4}$ \\
\hline 14 & Zeytinburnu 1 & $\mathbf{2 4}$ & 1 & Silivri & $\mathbf{1 3}$ \\
\hline 16 & Yedikule Gashouse & $\mathbf{2 4}$ & 28 & Büyükdere Match & $\mathbf{1 2}$ \\
\hline 39 & Kartal 1 & $\mathbf{2 4}$ & 2 & Bäyükçekmece & $\mathbf{1 1}$ \\
\hline 40 & Kartal 2 & $\mathbf{2 3}$ & 5 & Beylikdüzü 3 & $\mathbf{1 1}$ \\
\hline & & & & \\
\hline
\end{tabular}




\begin{tabular}{clcclc}
\hline 25 & $\begin{array}{l}\text { Ortaköy } \\
\text { Pharmaceutical Plant }\end{array}$ & $\mathbf{2 1}$ & 44 & Pendik 3 & $\mathbf{1 1}$ \\
\hline 13 & $\begin{array}{l}\text { Haznedar Brick } \\
\text { Factory }\end{array}$ & $\mathbf{2 1}$ & 20 & Sultangazi & $\mathbf{1 0}$ \\
\hline 9 & Bağcllar 1 & $\mathbf{2 1}$ & 43 & Pendik 2 & $\mathbf{1 0}$ \\
\hline 6 & Avclar & $\mathbf{2 0}$ & 3 & Beylikdüzü 1 & $\mathbf{7}$ \\
\hline 10 & Bağcılar 2 & $\mathbf{2 0}$ & & & \\
\hline
\end{tabular}

\section{Classification of idle industrial sites and industrial heritage areas by cultural development strategies}

The criteria were determined based on the spatial preferences of entrepreneurial, creative, and progressive cultural development strategies preferred by central and local governments (Table 5).

At this stage, each one of the designated idle industrial sites and industrial heritage sites were evaluated quantitatively based on the criteria specified. According to the evaluation method:

- "1 point" was assigned for each criterion that an area fulfills.

- The scores assigned for each criterion fulfilled by each area were added up separately on the basis of three strategic approaches.

- The total scores obtained for each one of the three strategic approaches were divided by the number of criteria of the relevant group. Thus, the point normalization of the three strategic approach groups was ensured.

- The scores obtained were proportioned in percentage format.

Table 5. Spatial selection criteria of different cultural development strategies

\begin{tabular}{|c|c|}
\hline Strategies & Criteria \\
\hline $\begin{array}{l}\text { Entrepreneurial } \\
\text { [ES] }\end{array}$ & 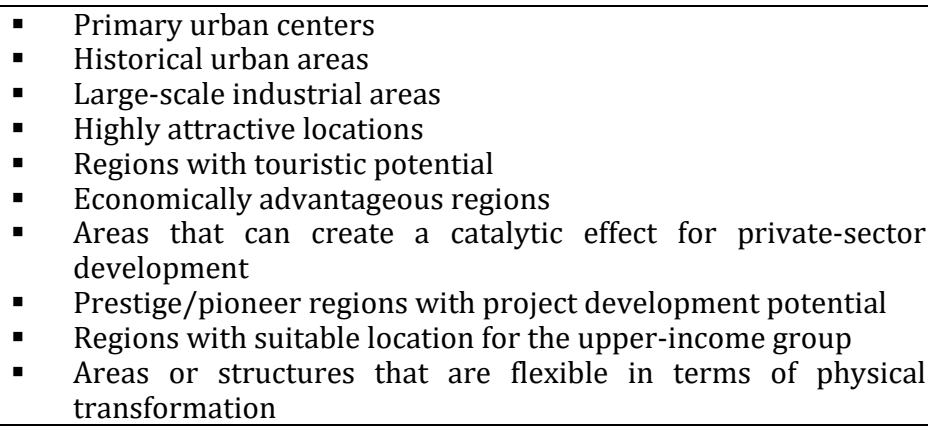 \\
\hline $\begin{array}{l}\text { Creative class } \\
{[\mathrm{CS}]}\end{array}$ & $\begin{array}{l}\text { - Areas with suitable location for the arts and entertainment } \\
\text { - } \text { functions } \\
\text { potential culture-focused regions with private enterprise } \\
\text { - Primary urban centers } \\
\text { - } \text { Historic urban centers } \\
\text { - } \text { Old urban areas } \\
\text { - Regions with a suitable location for education and research } \\
\text { Areas or structures that are flexible in terms of physical } \\
\text { development }\end{array}$ \\
\hline $\begin{array}{l}\text { Progressive } \\
\text { [PS] }\end{array}$ & $\begin{array}{l}\text { - } \quad \text { Secondary city centers } \\
\text { - } \quad \text { Regions with difficulty in access to services } \\
\text { - } \quad \text { Large-scale manufacturing areas } \\
\text { - } \quad \text { Areas of urban decay } \\
\text { Areas or structures that are flexible in terms of physical } \\
\text { exchange }\end{array}$ \\
\hline
\end{tabular}


Culture-led Urban Transformation Strategies For Industrial Heritage And Industrial Areas In Istanbul

The following formulas were used to calculate the scores of the fields according to the site selection criteria of different cultural development strategies:

Entrepreneurial strategies $=E S ; \quad$ Creative strategies $=C S ; \quad$ Progressive strategies=PS; Total point $=T P ;$ Percentage Distribution $=P D$

$$
\begin{aligned}
& \mathrm{ES}=\frac{1}{10} \sum_{\mathrm{i}=1}^{10} \mathrm{e}_{\mathrm{i}}, \mathrm{CS}=\frac{1}{7} \sum_{\mathrm{i}=1}^{7} \mathrm{c}_{\mathrm{i}}, \mathrm{PS}=\frac{1}{6} \sum_{\mathrm{i}=1}^{6} \mathrm{p}_{\mathrm{i}} \\
& \mathrm{TP}=\mathrm{ES}+\mathrm{CS}+\mathrm{PS}=\frac{1}{10} \sum_{\mathrm{i}=1}^{10} \mathrm{e}_{\mathrm{i}}+\frac{1}{7} \sum_{\mathrm{i}=1}^{7} \mathrm{c}_{\mathrm{i}}+\frac{1}{6} \sum_{\mathrm{i}=1}^{6} \mathrm{p}_{\mathrm{i}} \\
& \% \mathrm{E}_{\text {sose }}=\mathrm{PD}_{\mathrm{ES}}=100 . \mathrm{ES} \div \mathrm{TP}=100 . \mathrm{ES} \div(\mathrm{ES}+\mathrm{CS}+\mathrm{PS})=100 \cdot \frac{1}{10} \sum_{\mathrm{i}=1}^{10} \mathrm{e}_{\mathrm{i}} \div\left(\frac{1}{10} \sum_{\mathrm{i}=1}^{10} \mathrm{e}_{\mathrm{i}}+\frac{1}{7} \sum_{\mathrm{i}=1}^{7} \mathrm{c}_{\mathrm{i}}+\frac{1}{6} \sum_{\mathrm{i}=1}^{6} \mathrm{p}_{\mathrm{i}}\right. \\
& \% \mathrm{C}_{\text {soxe }}=\mathrm{PD}_{\mathrm{CS}}=100 . \mathrm{CS} \div \mathrm{TP}=100 . \mathrm{CS} \div(\mathrm{ES}+\mathrm{CS}+\mathrm{PS})=100 . \frac{1}{7} \sum_{\mathrm{i}=1}^{7} \mathrm{c}_{\mathrm{i}} \div\left(\frac{1}{10} \sum_{\mathrm{i}=1}^{10} \mathrm{e}_{\mathrm{i}}+\frac{1}{7} \sum_{\mathrm{i}=1}^{7} \mathrm{c}_{\mathrm{i}}+\frac{1}{6} \sum_{\mathrm{i}=1}^{6} \mathrm{p}_{\mathrm{i}}\right. \\
& \% \mathrm{P}_{\text {sece }}=\mathrm{PD}_{\mathrm{PS}}=100 . \mathrm{PS} \div \mathrm{TP}=100 . \mathrm{PS} \div(\mathrm{ES}+\mathrm{CS}+\mathrm{PS})=100 . \frac{1}{6} \sum_{\mathrm{i}=1}^{6} \mathrm{p}_{\mathrm{i}} \div\left(\frac{1}{10} \sum_{\mathrm{i}=1}^{10} \mathrm{e}_{\mathrm{i}}+\frac{1}{7} \sum_{\mathrm{i}=1}^{7} \mathrm{c}_{\mathrm{i}}+\frac{1}{6} \sum_{\mathrm{i}=1}^{6} \mathrm{p}_{\mathrm{i}}\right.
\end{aligned}
$$

Accordingly, a high percentage value indicates the most appropriate strategic approach for each area. However, strategic approaches with a value more than $30 \%$ were considered in order to embrace a flexible perspective in the policy-development process. Thus, the primary and secondary strategic approaches were identified for each area (Table 6) (Figure 5).

The industrial areas with the highest transformation potential are: Haliç Dockyards (30 points), Haydarpaşa Railway Station Machine Shop (30 points), Kasımpaşa Flour Factory (29 points), Dolmabahçe Gashouse (29 points), and Bomonti Beer Factory (28 points). As a result of the evaluation of these industrial areas according to the criteria that determine the cultural development strategies, Haliç Dockyards, Haydarpaşa Railway Station, Kasımpaşa Flour Factory, Dolmabahçe Gashouse, and Bomonti Beer Factory prove to be prominent for creative class strategies. The industrial areas with the lowest transformation potential are: Beylikdüzü-1 (7 points), Pendik-2 (8 points), Pendik-3 (10 points), and Sultangazi (10 points). Accordingly, the priority transformation scenarios for these industrial areas can be specified as progressive strategies for Beylikdüzü-1, entrepreneurial strategies for Pendik-2 and Pendik-3, and progressive strategies for Sultangazi. 
Table 6. Classification of industrial sites that bear transformation potential in İstanbul within the scope of cultural development strategies

\begin{tabular}{|c|c|c|c|c|c|c|c|}
\hline & 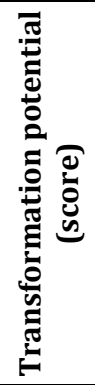 & D্d & & & 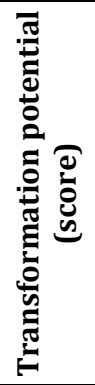 & 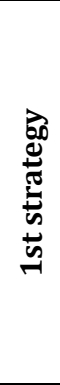 & 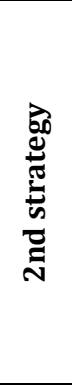 \\
\hline $\begin{array}{l}\text { Haydarpaşa Railway } \\
\text { Station Machine Shop }\end{array}$ & 30 & $\mathbf{E}$ & $\mathrm{C}$ & K.çekmece & 19 & $\mathbf{P}$ & $\mathrm{N} / \mathrm{A}$ \\
\hline Tuzla & 27 & $\mathbf{E}$ & $\mathrm{C}$ & Güngören & 18 & $\mathbf{P}$ & $\mathrm{E}$ \\
\hline Bakırköy 2 & 26 & $\mathbf{E}$ & $\mathrm{N} / \mathrm{A}$ & Gaziosmanpașa & 14 & $\mathbf{P}$ & $\mathrm{N} / \mathrm{A}$ \\
\hline Kağıthane 2 & 26 & $\mathbf{E}$ & $\mathrm{N} / \mathrm{A}$ & Beylikdüzü 2 & 14 & $\mathbf{P}$ & $\mathrm{N} / \mathrm{A}$ \\
\hline Kartal 3 & 26 & $\mathbf{E}$ & $\mathrm{N} / \mathrm{A}$ & Pendik 1 & 13 & $\mathbf{P}$ & $\mathrm{N} / \mathrm{A}$ \\
\hline Bayrampașa - Eyüp & 25 & $\mathbf{E}$ & $\mathrm{P}$ & Silivri & 12 & $\mathbf{P}$ & $\mathrm{C}$ \\
\hline Maltepe & 25 & $\mathbf{E}$ & $P$ & \begin{tabular}{|l|} 
Büyükdere Match \\
Factory
\end{tabular} & 12 & $\mathbf{P}$ & $\mathrm{C}$ \\
\hline Zeytinburnu 2 & 25 & $\mathbf{E}$ & $\mathrm{C}$ & B.çekmece & 11 & $\mathbf{P}$ & $\mathrm{E}$ \\
\hline Kağıthane 1 & 25 & $\mathbf{E}$ & $\mathrm{P}$ & Beylikdüzü 3 & 11 & $\mathbf{P}$ & $\mathrm{N} / \mathrm{A}$ \\
\hline Zeytinburnu 1 & 24 & $\mathbf{E}$ & $\mathrm{P}$ & Pendik 3 & 11 & $\mathbf{P}$ & $\mathrm{N} / \mathrm{A}$ \\
\hline Bahçelievler & 24 & $\mathbf{E}$ & $\mathrm{P}$ & Sultangazi & 10 & $\mathbf{P}$ & $\mathrm{N} / \mathrm{A}$ \\
\hline Kartal 1 & 24 & $\mathbf{E}$ & $\mathrm{P}$ & Beylikdüzü 1 & 7 & $\mathbf{P}$ & $\mathrm{E}$ \\
\hline Kartal 2 & 23 & $\mathbf{E}$ & $\mathrm{P}$ & Haliç Dockyards & 30 & $\mathbf{C}$ & $\mathrm{E}$ \\
\hline Bağclarar 1 & 21 & $\mathbf{E}$ & $P$ & $\begin{array}{l}\text { Kasımpaşa Flour } \\
\text { Factory }\end{array}$ & 29 & $\mathbf{C}$ & $\mathrm{E}$ \\
\hline Bakırköy 1 & 20 & $\mathbf{E}$ & $\mathrm{P}$ & Dolmabahçe Gashouse & 29 & $\mathbf{C}$ & $\mathrm{E}$ \\
\hline Atașehir & 19 & $\mathbf{E}$ & $\mathrm{C}$ & Bomonti Beer Factory & 28 & $\mathbf{C}$ & $E$ \\
\hline Ümraniye 2 & 17 & $\mathbf{E}$ & $\mathrm{P}$ & Yedikule Gashouse & 24 & $\mathbf{C}$ & $\mathrm{E}$ \\
\hline Ümraniye 1 & 17 & $\bar{E}$ & $\mathrm{~N} / \mathrm{A}$ & \begin{tabular}{|l|} 
Ortaköy \\
Pharmaceutical Plant
\end{tabular} & 21 & $\mathbf{C}$ & $E$ \\
\hline Pendik 2 & 10 & $\mathbf{E}$ & $\mathrm{P}$ & Beykoz Glass Factory & 19 & $\mathbf{C}$ & $\mathrm{N} / \mathrm{A}$ \\
\hline $\begin{array}{l}\text { Haznedar Brick } \\
\text { Factory }\end{array}$ & 21 & $\mathbf{P}$ & $\mathrm{E}$ & Beykoz Shoe Factory & 17 & $\mathbf{C}$ & $\mathrm{N} / \mathrm{A}$ \\
\hline Avclar & 20 & $\mathbf{P}$ & $E$ & Beykoz Distillery & 17 & $\mathbf{C}$ & $\mathrm{N} / \mathrm{A}$ \\
\hline Bağcrlar 2 & 20 & $\mathbf{P}$ & $\mathrm{E}$ & Beykoz Rope Factory & 15 & $\mathbf{C}$ & $\mathrm{N} / \mathrm{A}$ \\
\hline Beykoz Brick Factory & 19 & $\mathbf{P}$ & $\mathrm{N} / \mathrm{A}$ & & & & \\
\hline \multicolumn{2}{|c|}{ E: Entrepreneurial Strategies } & \multicolumn{6}{|c|}{ C: Creative Strategies } \\
\hline
\end{tabular}

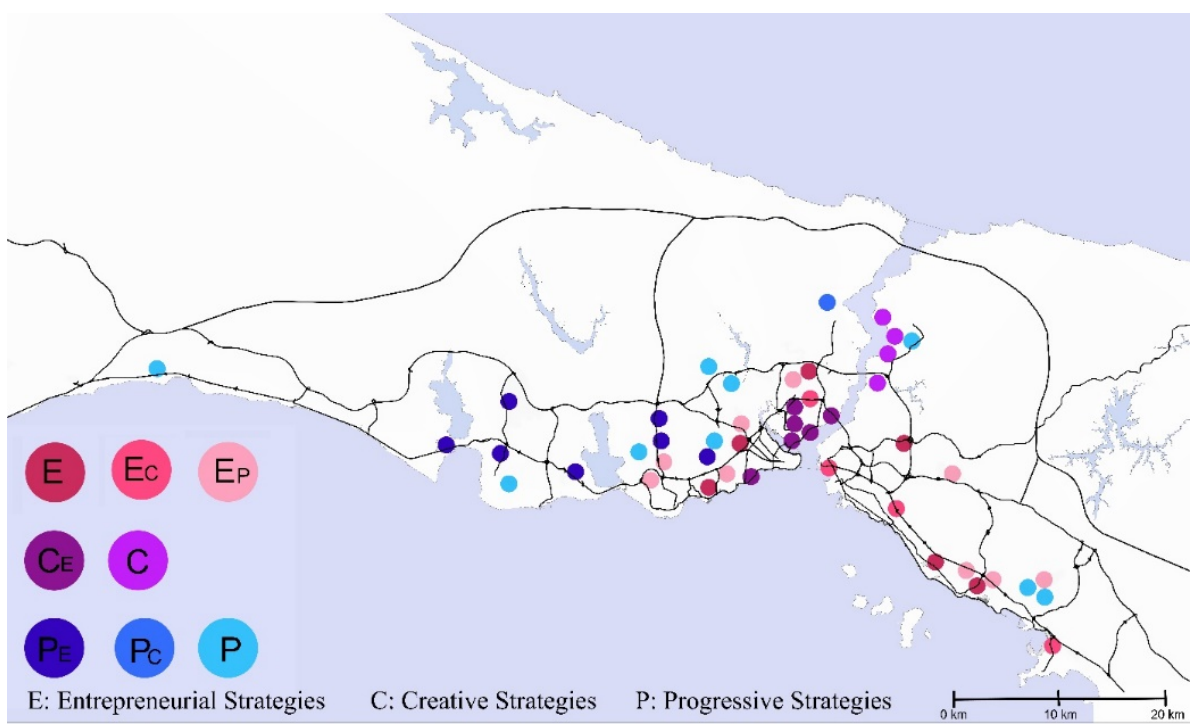

DISCUSSION AND CONCLUSION
Figure 5. Classification of industrial sites that bear transformation potential in İstanbul within the scope of cultural development strategies 
Since the mid-20th century, "culture" has been acknowledged as a significant theme in the urban transformation and revitalization programs aimed at protecting and reinforcing the character of cities, improving local economies, and ensuring a creative management. The emergence of a global service-based economy has placed culture in the heart of urban development and highlighted the economic value of culture in this process (Banks and O'Connor, 2017). This is an indication of the fact that culture industries and the creative workforce gain prominence each day. In this respect, the role of planners is to be involved in the urban development and the decision-making processes, to take lessons from past success and failures, and to promote "cultural planning" in various phases of spatial planning. However, cases where cultural activities in cities are used as a tool to market the city to consumers, tourists, and prospective investors or to support urban transformation should be handled deliberately (Degen and Gacia, 2012). As Kunzmann (2004) suggests, cultural activities should not be promoted at the expense of losing the local cultural environment. This may indeed easily lead to damages in the unique culture of a city as well as the forfeit of the informative and illuminating character of a city.

This study is focused on industrial sites that remain idle or that may be transformed, thus proving to be a potential for the proliferation of culture industries worldwide. It presents an approach to how a cultureled urban transformation scenario may be formulated within the scope of cultural development strategies (entrepreneurial, creative, progressive strategies) for the regeneration of the brownfields and the industrial sites that may be transformed in İstanbul.

According to the research, cultural projects and programs developed in line with entrepreneurial and creative class strategies are rather focused on old city centres and historic neighborhoods, and they bear a real-estate-oriented nature, thus departing away from the principle of public interest. In addition, it is well known that such strategies trigger gentrification in the project site and/or its vicinity; therefore, former residents of the project site who can no longer afford the escalating property values are forced to relocate (Grodach, O'Connor, and Gibson, 2017; Niu, Lau, Shen and Lau, 2018, p.516; Degen and Garcia, 2012, p.10-11). Consequently, it is possible to suggest that project sites that may be the subject of entrepreneurial and creative class strategies are vulnerable when it comes to the sustainability of the social structure. Progressive strategies, on the other hand, entail a rather fair distribution of the economic advantages to all segments of society, and they are the primary approach adopted in this study. Progressive strategies seek to ensure a just redistribution of the value generated as a consequence of culture-led transformation projects. The results of the surveys conducted by Grodach and Loukaitou-Sideris (2007) in order to understand the local cultural development strategies also indicate that local governments and the private sector share the same perspective. Grodach and Loukaitou-Sideris drew the conclusion that all three 
models have been utilized in the cities they analyzed, while further attention was given to entrepreneurial strategies. On the other hand, it was observed that cities where creative and progressive strategies are adopted have a bigger budget and are already prominent with their cultural strategies.

The present study demonstrates the strategic approaches that may be formulated for brownfields and industrial heritage sites in İstanbul with reference to the analytical evaluation of the spatial preferences of the three approaches mentioned above (Table 7). The primary purpose in doing so is to stay one step ahead to ensure that planners formulate balanced policies between the culture consumed in the global system and the local culture and to formulate plans and programs that consider public interest to shape the dispositions of the private sector. It is apparent that addressing idle industrial heritage sites or brownfields merely with entrepreneurial strategies poses great risk. New functions informed by creative industries and progressive policies may indeed contribute to the development of the cultural infrastructure in a city.

According to the analysis performed in scope of the present study, the researchers suggest that 45 brownfields in İstanbul are appropriate for culture-led transformation scenarios. Without question, this study does not indicate that all 45 sites should be transformed in scope of cultural development policies. However, emphasis is put on the fact that these sites may be evaluated in scope of cultural development policies, and further explanation is provided on those strategies that may be considered with priority. Accordingly, the researchers suggest that creative strategies should be developed in Fatih, Beyoğlu, Beşiktaş, and Beykoz districts, entrepreneurial strategies should be formulated in Kartal, Maltepe, Tuzla, Ümraniye, Şişli, and Zeytinburnu districts, and progressive strategies should be created in Kurtköy, Sultangazi, Bayrampaşa, Küçükcekmece, Beylikdüzü, and Silivri districts. In addition, an alternative development scenario is provided for each site. $\mathrm{Bu}$ doing so, entrepreneurial strategies that may prove to be an economic attraction for the city, creative strategies that present value in the competition between cities, and progressive strategies that may help improve the social-spatial infrastructure of the city may be thoroughly discussed in respect to the planning process in İstanbul. When planning for the future, handling project sites with reference to cultural development strategies is critical for local economic development and quality of life. On the other hand, addressing transformation sites with an entrepreneurial perspective to ensure the highest return leads to missed opportunities that would otherwise enable competitive advantage and social quality of life for creative industries at the global scale.

Future urban issues and new economic crisis that may accompany the rapid economic return ensured by the quick marketing of urban culture, which lies beneath the decision to opt for entrepreneurial approaches, should not be ignored. Cities may face the risk of gentrification due to 
public-private partnerships in which local governments only adopt entrepreneurial and creative class strategies. Progressive approaches not only provide employment opportunities but also enable urban citizens to contribute to culture and art. Based on the experiences in cities (such as Barcelona, Tampere, Dortmund, Nollendorf, Essen, Helsinki, Birmingham, and Beijing) where transformation scenarios were realized by means of progressive strategies (Degen and Gacia, 2012; Niu, Lau, Shen and Lau, 2018) such contributions can be summarized as follows:

- Ensuring the active involvement of the representatives of civil society in the strategic planning process,

- Including iconic buildings in the cultural heritage listing in order to preserve the industrial heritage and memory on the site,

- Integrating industrial sites with the city centre in terms of function, traffic, and urban design,

- Making investments aimed at creating public spaces while preserving the former urban fabric,

- Increasing the appeal of the industrial site for economic, commercial, and non-commercial activities, and enabling marketing and branding by means of the built environment,

- Creating an inspiring environment that hosts all kinds of activities intrinsic to the city centre,

- Ensuring that a diverse cultural environment is part of the everyday life of the city's residents,

- Improving access to culture by creating a robust social and cultural infrastructure to meet the social needs of the local community,

- Mobilizing cultural energy to create a vibrant local economy, and socioeconomic improvement.

Brownfields and industrial heritage sites that bear the potential for culture-led transformation should be addressed within a corporate and regulatory context to eliminate the social and economic inequalities in the urban space. It is suggested that cultural actors involved at the local scale should concentrate on progressive strategies that revolve around the interests and efforts of the citizens of the city. It is also necessary to highlight the importance of the existence of regulatory and supervisory authorities in such an approach.

\section{ACKNOWLEDGEMENTS/NOTES}

1. The unpublished first version of this study was presented in the 21. Urban Design and Applications Symposium as an oral presentation. In this latest version of the study, the literature review, the database, and the fieldwork were accordingly updated and revised.

2. Florida (2003:8) divides creative class into two groups: "SuperCreative Core" and "Creative Professionals." The Super-Creative Core includes scientists, engineers, university professors, poets and novelists, 
artists, actors, designers and architects as well as the leaders of modern society, science fiction writers, editors, cultural figures, analysts, and opinion makers.

3. According to TÜİK data, the share of employment in the manufacturing industry makes up $31.5 \%$ of the total employment in İstanbul in 2018 (İŞKUR, 2018: 29).

\section{FINANCIAL DISCLOSURE}

The authors declared that this study has received no financial support.

\section{CONFLICT OF INTEREST}

No conflict of interest was declared by the authors.

\section{ETHICS COMMITTEE APPROVAL}

Ethics committee approval was not required for this article.

\section{LEGAL PUBLIC/PRIVATE PERMISSIONS}

In this research, the necessary permissions were obtained from the relevant participants (individuals, institutions, and organizations) during the survey and in-depth interviews.

\section{REFERENCES}

Adorno, T, W. (2009). Cultural Industry Cultural Management (J. M. Bernstein , Dü., N. Ülner, M. Tüzel, \& G. Elçin, Translate.). İstanbul: İletişim Publications.

Banks, M., and Hesmondhalgh, D. (2009). Looking for work in creative industries policy. Intermational Journal of Cultural Policy, 415-430.

Banks, M., and O'Connor, J. (2017). Inside the whale (and how to get out of there): Moving on from two decades of creative industries research. European Journal of Cultural Studies, 20(6) 637-654.

Bontje, M. and Musterd, S. (2009), "Creative Industries, Creative Class and Competitiveness: Expert Opinions Critically Appraised", Geoforum, 40 (5): 843-852.

Camerin, F. (2019). From "Ribera Plan" to "Diagonal Mar", passing through 1992 "Vila Olímpica". How urban renewal took place as urban regeneration in Poblenou district (Barcelona). Land Use Policy , 89:1-14.

Chiu, Y.-H., Lee, M.-S., and Wang, J.-W. (2019). Culture-led urban regeneration strategy: An evaluation of the management strategies and performance of urban regeneration stations in Taipei City. Habitat International , 1-9.

Cengizkan, M. (2012). Sanayinin Terkettiği Yerlerde Yeniden Mimari. Güneymimarlık, 26-28.

Çelik, Ş. (2011). Culture Industry Three Wrongs One Right. İstanbul: Literatür.

Degen, M., and Gacia, M. (2012). The Transformation of the 'Barcelona Model': An Analysis of Culture, Urban Regeneration and Governance. International Journal of Urban and Regional Research, 1-16. 
Culture-led Urban Transformation Strategies For Industrial Heritage And Industrial Areas In Istanbul

Evans, G. (2005). Measure for Measure: Evaluating the Evidence of Culture's Contribution to Regeneration. Urban Studies 5 (6): 959-983.

Florida, R. (2003). Cities and the Creative Class. City \& Community 2:1319.

Garcia, B. (2004). Cultural Policy and Urban Regeneration in Western European Cities: Lessons from Experience, Prospects for the Future. Local Economy, 19 (4): 312-326.

Grodach, C., (2017). Urban cultural policy and creative city making. Cities, 82-91.

Grodach, C. and Loukaitou-Sideris A. (2007). Cultural Development Strategies and Urban Revilatalization. International Journal of Cultural Policy. 13(4): 349- 370.

Grodach, C., O'Connor, J., \& Gibson, C. (2017). Manufacturing and cultural production: Towards a progressive policy agenda for the cultural economy. City, Culture and Society, 17-25.

Hospers, G. J., and Pen, C. (2008). A View on Creative Cities Beyond The Hype. Creativity and Innovation Management 4: 259-270.

IMM, (2018). Istanbul Metropolitan Municipality Official Database, İstanbul.

IMP, (2006a). Cultural industries development districts. Istanbul Metropolitan Planning and Urban Design Office.

IMP, (2006b). 1/100000 Draft Environmental Plan. Istanbul Metropolitan Planning and Urban Design.

IMP, (2009). 1/25000 Environmental Plan. Istanbul Metropolitan Planning and Urban Design Office.

ISKUR, (2018). Labour Market Research Report, General Directorate Of Turkish Employment Agency, Istanbul Labour And Employment Agency Provincial Directorate, 2018 - pp. 29

Kunzmann, K., R. (2004). Culture, creativity and spatial planning. The Town Planning Review 75(4): 383-404.

Koramaz, K.(2016).Land Use Suitability Analysis: Analysis And Evaluation Techniques In Urban Planning. Istanbul: Literatür Publications, pp. 129-134

Köksal, T. G. (2012). Endüstri Mirasını Korum ve Yeniden Kullanım Yaklaşımı. Güneymimarlık , 8:18-23.

Köksal, T. G., and Ahunbay, Z. (2006). Some proposals for the conservation and reuse of industrial heritage in Istanbul, ITU Journal of Faculty of Architecture, 5(2):125-136.

Lavanga, M. (2009). Culture and Cities. Urban Transformation and Sustainable Urban Configuration. In: S. Ada (Ed.) Cultural Policies and Management (KPY) Annual 2009. Istanbul: Bilgi University Publications, pp. 61-74

Marshall, T. (2000). Urban Planning and Governance: Is there a Barcelona Model? . International Planning Studies, 5(3) : 299-319. 
Montgomery, J. (2003). Cultural Quarters as Mechanisms for Urban Regeneration. Part 1: Conceptualising Cultural Quarters. Planning, Practice \& Research, 293-306.

Montgomery, J. (2007). Creative Industry Business Incubators and Managed Workspaces: A Review of Best Practice. Planning, Practice \& Research, 601-617.

Niu, S., Lau , S., Shen , Z., and Lau, S. (2018). Sustainability issues in the industrial heritage adaptive reuse: rethinking culture-led urban regeneration through Chinese case studies. ournal of Housing and the Built Environment, 33: 501-518.

Özdemir, N. (2009). The Relation Between Cultural Economy and Cultural Industries with Cultural Heritage Management, The Journal of National Folklore, 73-86.

Peck ,J. (2005). Struggling with the Creative Class. International Journal of Urban and Regional Research, 29(4) : 740-770.

Saner, M. (2011). Transforming the industrial landscape: large scale artworks in Iba Emscher Park. In: Akdeniz University Faculty of Fine Arts International Art / Design and Aesthetic Theories Symposium Book, pp.270-277

Teper, S. (2002). Creative Assets and the Changing Economy. The Journal of Arts Management, Law, and Society, 3 (2): 159-168.

Trembath, J.-L., and Fielding, K. (2020). Australia's cultural and creative economy: A 21st century guide. Canberra: Australian Academy of the Humanities.

\section{Resume}

Serkan Sinmaz received his Ph. D. from Ylldiz Technical University, Department of Urban Planning in 2014. Between 2008 and 2017, he worked as a research assistant and lecturer at Ylldiz Technical University. He currently works as an associate professor at Kırklareli University, Department of Urban and Regional Planning.

Asl Altanlar received her Ph. D. from Yıldiz Technical University, Department of Urban Planning in 2015. She worked as a research assistant in the Department of Urban and Regional at Ylldiz Technical University, between 2010 and 2015 respectively. She currently works as an assistant professor at Amasya University, Department of Urban and Regional Planning. 